\title{
Comparative Survey of Litter Arthropods and Soil Mesofauna in the Natural Forest and Plantation (a Case Study: Akure Forest Reserve Aponmu)
}

\author{
Adeduntan Sunday Adeniyi, Olusola Johnson Adeyinka* \\ Department of Forestry and Wood Technology, Federal University of Technology, Akure, Nigeria
}

\begin{abstract}
The abundance and species diversity of mesofauna and litter arthropods were surveyed in the natural forest and three plantations (Nauclea diderichii, Gmelina arborea and Tectona grandis plantations) in Akure Forest Reserve, Aponmu Nigeria to examine the effect of plantation development on both the abundance and species diversity of litter arthropods and mesofauna. The effect of microorganism's abundance and species diversity on their abundance and species diversity was also assessed. Sample Plot of $100 \mathrm{~m} \times 100 \mathrm{~m}$ blocks were laid in each habitat. Soil samples were taken from the selected sample plots to isolate and identify mesofauna and microorganisms while litter arthropods caught were preserved and identified. During the survey, 1165 individuals of mesofauna were encountered (distributed in 23 species) in all the studied habitats. Mesofauna abundance was highest in Gmelina arborea plantation (334 individuals) while Nauclea diderichii plantation has the least abundance of 201 individuals. Highest species diversity was recorded in Natural forest with 23 species while the least species diversity was found in the Tectona grandis plantation. 64 individual of litter arthropods were however encountered in the study area (distributed in 27 species). Natural forest accounts for the highest in both the species diversity and abundance (i.e. 21 individuals and 11 species respectively.) Tectona grandis accounts for the least species diversity in the studied habitats (5 species) and Gmelina arborea plantation has the least abundance of litter arthropods (12 individuals).
\end{abstract}

Keywords Natural Forest, Arthropods, Microorganism, Plantation, Mesofauna

\section{Introduction}

Arthropods are the most successful member of the Animal Kingdom; more than $80 \%$ of the described living Animal species are Arthropods (Anna-Thanukos, 2007). Phylum Arthropoda, which includes more than one million species, is the largest in the animal kingdom and is represented by nine classes of segmented animals with paired, jointed appendages and a hard exoskeleton. They are common throughout marine, freshwater, terrestrial and even aerial environments. Insects are seen to be the most successful of the known terrestrial Arthropods. However there are several other families in the Phylum Arthropoda which are important to the Forest Eco-system.

Arthropods are of economic and ecological importance in the Forest Eco-system and their abundance and species diversity are of great interest to the Entomologists. The role played by soil and litter arthropods in the decomposition processes and continuous release of nutrient to the forest soil

* Corresponding author:

johnsonolusola5@gmail.com (Olusola Johnson Adeyinka)

Published online at http://journal.sapub.org/ijaf

Copyright (C) 2012 Scientific \& Academic Publishing. All Rights Reserved is of great interest, through experiment, (Crossley and Blumberg, 1997) confirmed the significance of soil fauna in decomposition and litter transformation. However, Arthropods are also responsible for some activities in the Forest Eco-system that are detrimental to the Forest Environment (especially on the tree community) examples of these are: some Arthropods serves as vectors to some tree's diseases and pests and some (especially the insects e.g. defoliators) are directly pests on forest trees. Although several research works had been carried out on the abundance of Arthropods in the various Eco-systems (Forest Eco-system inclusive) for example, (Marshall, et al 1994, Adeduntan et. al. 2005 and Adeduntan 2009) studied the terrestrial arthropod biodiversity, not much have been done on the survey of soil and litter Arthropods in the Forest Eco-system.

This research work is therefore to carry out comparative survey of litter arthropods and soil mesofauna in the natural forest and plantation Akure forest reserve Aponmu Nigeria, as well as to examine the relationship between Litter arthropod and mesofauna, litter arthropod and microorganisms, mesofauna and microorganism.

\section{Methodology}




\section{Study Area}

The survey was carried out in Akure Forest Reserve. Located at Aponmu village in Akure south Local Government Area of Ondo State, Nigeria. The reserve covers an area of $69.93 \mathrm{~km}^{2}$ and the areas surveyed are selected from the permanent sampling plot of the natural forest and adjacent plantations (i.e. Tectona grandis, Gmelina arborea and Nauclea diderichii plantation).

The Akure forest reserve lies on a general altitude of $279 \mathrm{~m}$ above sea level. The soil is well drained due to the presence of Owena River which flow from north to south across the forest reserve into the Atlantic Ocean.

According to the brief description of the forest reserve by Ola-Adams and Hill (1987) the underlying rock is crystalline mainly gneiss and referable to the basement complex. As a result of weathering ferric luvisol soil is present in the forest reserve.

The climate is humid tropical with seasonal variation. The mean annual rainfall is about $4000 \mathrm{~mm}$ with double maximum in the months of July and September and short relatively dry period in August, between December and February constitute the major dry season while January and February are the driest months with each having less than $30 \mathrm{~mm}$ rainfall (Ola-Adams and Hill, 1987). Temperature range from about $20.6^{\circ} \mathrm{C}$ to $33.5^{\circ} \mathrm{C}$ the monthly temperature is about $27^{\circ} \mathrm{C}$ a condition that is conducive to the development of tropical rain forest.

\section{Data Collection}

A permanent sample block of $100 \times 100 \mathrm{~m}^{2}$ is demarcated in each habitat (i.e. Natural forest, Tectona grandis, Gmelina arborea and Nauclea diderichii plantation). Each block was then sub-divided into smaller plots of $20 \times 25 \mathrm{~m}^{2}$ and six plots were randomly selected from each habitat. The top soil (0-10 cm depth) samples were collected from each plot. The soil was collected diagonally at three points and was thoroughly mixed together.

\section{Isolation of Soil Mesofaunas}

The isolation of soil mesofauna was done in the laboratory using the flotation method. About $100 \mathrm{~g}$ of the soil that were collected was placed in a Petri-dish and mixed with water (this will help coagulate the constituents of the soil so the soil Mesofauna can be viewed). The soil is then viewed under microscope to identify the various species and abundance of soil mesofauna present in the soil sample.

\section{Collection of Litter Arthropods}

The litter arthropods were collected by trapping (i.e. pitfall) which makes use of a dish sunk in the earth and covered at the top to exclude rain and small vertebrates while allowing Arthropods to enter the pitfall. Bait was placed in the dish to trap the arthropods. The trapped arthropods were collected after 24 hours in a container.

\section{Isolation of Microorganisms}

The standard procedures for determining the total number of soil microbes were adopted for bacteria and fungi culturing (Alexander, 1982). Suspension of the soil samples was prepared with sterile water and a serial dilution of five factors was made for accurate counting. Then $1 \mathrm{ml}$. of the ap- propriate dilution was carefully transferred to sterilized Petri dishes containing sterile molten nutrient agar at about $370 \mathrm{C}$. This was mixed and allowed to solidify. It was then incubated for $24 \mathrm{~h}$. The bacteria that grew into colonies were sub-cultured to obtain pure culture for easy identification. Identification was done according to Bergeys manual of determinative bacteriology.

For fungi culturing, serial dilution of the suspension was also transferred into Petri dishes containing sterile, molten malt extract agar. This was kept in an incubator at $300 \mathrm{C}$ for 5 days. Fungi that grew were sub-cultured to obtain pure culture for easy identification. Microscopic characterization was done for identification.

\section{Data Analysis}

The results were subjected to analysis of variance (ANOVA)

\section{Results}

The result of the effect of plantation development on the mesofauna abundance is presented in Table 1. 1165 individuals were encountered in all in the study area. The Gmelina arborea plantation account for the highest abundance of mesofauna (334 individuals in all) followed by Tectona grandis plantation (316 individuals), natural forest (314 individuals) while Nauclea diderichii plantation has the least abundance of 201 individuals for the four trips to the studied habitats.

The result also show that Acrobeloidea spp was found to have the highest number of individuals (114 individuals) and it cutting across all the studied habitats, while Aporrectodae caliginosa was seen to have the least number of individuals (11) occurring in only two habitats (i.e. Natural forest and Tectona grandis plantation) throughout the whole duration of the period of study.

The result of the effect of plantation development on the mesofauna species diversity is presented in Table 2. 23 species were encountered in the four studied habitats, the natural forest recorded the highest species diversity of 23 species followed by Nauclea diderichii plantation (21 species), Gmelina arborea plantation (20 species) while the least species diversity was found in the Tectona grandis plantation.

Most of the species encountered in the study area were common to all the habitats e.g. Tullbagia granilata, Spirosteptus spp, Caenorhabditis elegans, Mesodiplogaster inheriteri etc. Aporrectodae caliginosa was found in only two habitats (i.e. natural forest and Tectona grandis plantation), while species like Dorylus fimbriatus, Acanthamoeba pilyphages, e.t.c where found in three habitats each in the study area. However none of the species appears in a single habitat in the study area.

Table 3 shows that 207 individuals of litter arthropods were encountered per hectare of the study area, the natural forest accounts for the highest frequency of individuals (67) individuals, followed by Tectona grandis plantation (52) then Nauclea diderichii plantation (49) while Gmelina ar- 
borea plantation have the least (39 individuals/hec).

The result of the effect of plantation development on the litter arthropods species diversity is presented in Table 4. 27 species of litter arthropods were encountered in the studied habitat. Natural forest also accounts for the highest species diversity of litter arthropods (11 species) followed by $\mathrm{Nau}$ clea diderichii plantation ( 8 species) while Gmelina arborea plantation recorded 7 species Tectona grandis plantation recorded the least ( 5 species).

Ants also recorded the highest species diversity. Ants is present in all the habitats of the studied area Cassutia flaveole and spider were also found to be common to three habitats of the studied habitats, while Sinoxylon senegalensis and millipedes were found in two habitats of the studied habitat. Species like Capius spp and Chrysolagria colgi are found in only one habitats of the studied area.

ANOVA, table 5 shows that the effect of plantation development is not significant $(\mathrm{P} \geq 0.05)$ on the abundance of the mesofauna. Also the block effect, show that the effect of the different period of mesofauna collection or sampling was not significant $(\mathrm{P} \geq 0.05)$ on the abundance of the mesofauna.

ANOVA table 6 shows that the effect of plantation development is not significant on abundance and the species diversity of the mesofauna, likewise the period of collection or sampling of mesofauna is not significant.

The result of the effect of plantation development on the bacteria's species diversity is presented in Table 7; thirty three (33) species of bacteria were encountered in during the study. The highest species diversity was recorded in Tectona grandis plantation with 16 bacteria species, followed by natural forest with 15 species, 13 species were observed in Nauclea diderichii and Gmelina arborea plantation respectively.

The species that are commonly found in at least three habitats were: Proten mirobilis, Alkaligenes spp, Pseudomonas aeniginosa, Methylococcus spp, Acetobacta spp, Bacillus cereus and Staphylococus aureus, while those found in one habitat only were: Chrrobacterium spp, Bacillus megaterium, Roteus megaterium, Micrococus luteus, Aeromonas spp, Agrobacterium spp, Cellulomonas spp, Klebsiolla spp, Proteus vulgaris, Corygnebacteriu spp, Clostridium sporegenes, Pseudomonus syrindea and Clostridium plagarium. Most of which are found in the natural forest. The rest (e.g. Eruginia amyloiora, Bacillus subtilis) where found in at least two of habitat of the study area. However none of the bacterial species appeared in all the four habitats together.

The result of the effect of plantation development on fungi species diversity is presented in Table 8. Forty four (44) species of fungi where encountered in the studied habitat, during the study. The highest fungus species diversity was encountered in Gmelina arborea plantation with 19 different species followed by Nauclea diderichii plantation (15 species) while fungi diversity were least in Natural forest and Tectona grandis plantation (each with 13 species)

The species that were most commonly found in at least three habitats were: Penicillium italium, Aspergillus niger, Aspergillus furigatus and Verticillium alboratrium most of the fungi species appeared in only one of the habitats e.g. Sreptothrix spp, Gyrothrix ancinta, Aspergillus flavus, e.t.c while others appeared in at least two habitats of the study area e.g. Ovilaris oviculoris, Chloridium chlamydosporus, Streptotrix atra. However none of the fungal species appeared in all the four habitats together.

ANOVA table 9 show that the effect of plantation development on abundance of bacteria and fungi species was not significant $(\mathrm{P} \geq 0.05)$.

Table 10 shows that relationship between the abundance of mesofauna and litter arthropods is not significant $(\mathrm{P}>$ 0.05). The rate at which the change in the abundance of mesofauna affects the abundance of litter arthropods in the habitats is very low $(\mathrm{R}=0.1326)$. The result further shows that a change in mesofauna abundance will cause about $1.7 \%$ change in litter arthropods abundance.

Table 10 shows that relationship between species diversity of mesofauna and litter arthropod is significant $(\mathrm{P} \leq 0.05)$. The rate at which the change in the species diversity of mesofauna affects that of litter arthropods in the habitats studied is very high $(\mathrm{R}=0.9954)$. The result also shows that a change in mesofauna species diversity will cause about $99 \%$ change in litter arthropods species diversity.

The regression equation showing the relationship between the abundance of bacteria and mesofauna is not significant $(\mathrm{P}$ $\geq 0.05$ ). The changes in the abundance of bacteria affects that of mesofauna is very low $(\mathrm{R}=0.0246)$. The further shows that a change in bacteria abundance will cause about $0.06 \%$ change in mesofauna abundance.

The regression equation of the relationship between the species diversity of bacteria and mesofauna is no significant $(\mathrm{P}>0.05)$, the rate at which the change in the species diversity of bacteria affects that of mesofauna in the habitats studied is very low $(\mathrm{R}=0.0976)$ The result also shows that a change in bacteria species diversity will cause about $0.95 \%$ change in mesofauna specie diversity.

There is no significant regression equation in the relationship between the abundance of fungi and mesofauna $(\mathrm{P}>$ 0.05 ), the rate at which the change in the abundance of fungi affects that of mesofauna in the habitats studied is very low $(\mathrm{R}=0.0513)$. The result also shows that a change in fungi abundance will cause about $0.26 \%$ change in mesofauna abundance.

The regression equation of the relationship between the species diversity of fungi and mesofauna is no significant $(\mathrm{P}>0.05)$, the change in the species diversity of fungi affects that of mesofauna in the habitats is very low $(\mathrm{R}=0.2760)$ This implies that a change in fungi species diversity will cause about $7.8 \%$ change in mesofauna species diversity.

The regression equation of the relationship between the abundance of bacteria and litter arthropods is no significant $(\mathrm{P}>0.05)$, the rate at which the changes in the abundance of bacteria affects litter arthropods in the habitats is fairly high $(\mathrm{R}=0.6943)$. The result further indicated that a change in 
bacteria abundance will cause about $48 \%$ change in litter arthropods abundance.

The regression equation of the relationship between the species diversity of bacteria and litter arthropods is no significant $(\mathrm{P}>0.05)$, the changes in the species diversity of bacteria affects litter arthropods in the habitats is very low $(\mathrm{R}$ $=0.1556)$ The result also shows that a change in bacteria species diversity will cause about $2.5 \%$ change in litter arthropods species diversity.

The regression equation of the relationship between the abundance of fungi and litter arthropods is not significant $(\mathrm{P}>0.05)$, the rate at which the change in the abundance of fungi affects that of litter arthropods in the habitats is fairly high $(\mathrm{R}=0.6979)$ which implies that a change in fungi abundance will cause about $49 \%$ change in litter arthropods abundance.

The regression equation between the species diversity of fungi and litter arthropods is not significant $(\mathrm{P}>0.05)$, the rate at which the change in the species diversity of fungi affects that of litter arthropods is very low $(\mathrm{R}=0.1885)$ The result also shows that a change in fungi species diversity will cause $3.6 \%$ change in litter arthropods species diversity.

The table 11 shows that there is a weak negative correlation between litter arthropod's abundance and mesofauna abundance, it also reveals that there is a fairly strong negative correlation between the litter arthropod's abundance and fungi count and bacteria and fungi count. However there was a fairly strong positive correlation between litter arthropod's abundance and bacteria count while the correlation between mesofauna abundance and bacteria count and mesofauna abundance and fungi count were very weak.

From the table 12, there was a strong positive correlation between the species diversity of litter arthropods and that of the mesofauna in the studied habitats while the correlation between the species diversity of litter arthropods and bacteria and fungi and mesofauna respectively was negatively week, also the correlation between the species diversity of bacteria and fungi is negatively strong.

Table 1. The abundance of mesofauna in the four studied habitats

\begin{tabular}{|c|c|c|c|c|c|c|}
\hline \multirow[t]{2}{*}{ Family } & \multirow[t]{2}{*}{ Species } & \multicolumn{5}{|c|}{ Abundance per $100 \mathrm{~g}$ of soil } \\
\hline & & $\begin{array}{c}\text { Natural } \\
\text { forest }\end{array}$ & $\begin{array}{l}\text { N. diderichii } \\
\text { plantation }\end{array}$ & $\begin{array}{l}\text { G. arborea plan- } \\
\text { tation }\end{array}$ & $\begin{array}{l}\text { T. grandis } \\
\text { plantation }\end{array}$ & Total \\
\hline Collembola & Tullbagia granilata & 11 & 6 & 12 & 17 & 46 \\
\hline Arthropoda & Spirosteptus spp & 9 & 10 & 19 & 4 & 42 \\
\hline Anelida & Lumbricus rubellus & 6 & 6 & 16 & 15 & 43 \\
\hline Arthropoda & Caenorhabditis elegans & 7 & 18 & 5 & 49 & 79 \\
\hline Nematoda & Acrobeloidea spp & 18 & 14 & 46 & 36 & 114 \\
\hline Nematoda & Mesodiplogaster inheriteri & 59 & 2 & 10 & 27 & 98 \\
\hline Insecta & Dorylus fimbriatus & 36 & 11 & 30 & 0 & 77 \\
\hline Collembola & Fulsomia candida & 3 & 2 & 13 & 7 & 25 \\
\hline Insecta & Colpoda steinii & 25 & 10 & 25 & 15 & 75 \\
\hline Arthropoda & Glomeris maginata & 13 & 10 & 28 & 10 & 61 \\
\hline Nematoda & Acanthamoeba pilyphages & 14 & 16 & 4 & 0 & 34 \\
\hline Insecta & Microtermitinae spp & 16 & 10 & 16 & 10 & 52 \\
\hline Macroarthropoda & Pocellio scober & 9 & 22 & 3 & 0 & 34 \\
\hline Anelida & Allolobophora trapezoides & 6 & 3 & 10 & 16 & 35 \\
\hline Anelida & Aporrectodae trapezoides & 6 & 2 & 15 & 4 & 27 \\
\hline Anelida & Hyperiodilus africanus & 7 & 0 & 9 & 26 & 42 \\
\hline Nematoda & Rhabditis spp & 14 & 4 & 9 & 8 & 35 \\
\hline Insecta & Ancistrotermes cerithorax & 8 & 6 & 0 & 31 & 45 \\
\hline Anelida & Allolobophora coliginosa & 13 & 18 & 0 & 18 & 49 \\
\hline Insecta & Myrmicaris striata & 16 & 10 & 27 & 14 & 67 \\
\hline Anelida & Eudrilus eugeniae & 6 & 0 & 28 & 0 & 34 \\
\hline Macroarthropoda & Oniscus asellus & 10 & 21 & 9 & 0 & 40 \\
\hline Anelida & Aporrectodae caliginosa & 2 & 0 & 0 & 9 & 11 \\
\hline & Total & 314 & 201 & 334 & 316 & 1165 \\
\hline
\end{tabular}

Table 2. The species diversity of mesofauna in the four studied habitats

\begin{tabular}{|c|c|c|c|c|c|}
\hline Family & Species & Natural forest & $\begin{array}{c}\text { Nauclea Diderichii } \\
\text { plantation }\end{array}$ & $\begin{array}{c}\text { Gmelina arborea } \\
\text { plantation }\end{array}$ & $\begin{array}{l}\text { Tectona gran- } \\
\text { dis plantation }\end{array}$ \\
\hline Collembola & Tullbagia granilata & $*$ & $*$ & $*$ & $*$ \\
\hline Arthropoda & Spirosteptus spp & $*$ & $*$ & $*$ & $*$ \\
\hline Anelida & Lumbricus rubellus & $*$ & $*$ & $*$ & $*$ \\
\hline Arthropoda & Caenorhabditis elegans & * & * & * & * \\
\hline Nematoda & Acrobeloidea spp & * & $*$ & $*$ & $*$ \\
\hline Nematoda & Mesodiplogaster inheriteri & $*$ & $*$ & $*$ & $*$ \\
\hline Insecta & Dorylus fimbriatus & $*$ & $*$ & $*$ & \\
\hline Collembola & Fulsomia candida & $*$ & $*$ & $*$ & * \\
\hline Insecta & Colpoda steinii & $*$ & $*$ & $*$ & $*$ \\
\hline Arthropoda & Glomeris maginata & $*$ & $*$ & $*$ & $*$ \\
\hline Nematoda & Acanthamoeba pilyphages & * & * & * & \\
\hline Insecta & Microtermitinae spp & $*$ & $*$ & $*$ & * \\
\hline Macroarthropoda & Pocellio scober & $*$ & $*$ & $*$ & \\
\hline Anelida & Allolobophora trapezoides & $*$ & $*$ & $*$ & * \\
\hline Anelida & Aporrectodae trapezoides & $*$ & $*$ & $*$ & $*$ \\
\hline Anelida & Hyperiodilus africanus & $*$ & & $*$ & $*$ \\
\hline Nematoda & Rhabditis spp & * & 承 & $*$ & * \\
\hline Insecta & Ancistrotermes cerithorax & $*$ & $*$ & & $*$ \\
\hline Anelida & Allolobophora coliginosa & $*$ & $*$ & - & $*$ \\
\hline Insecta & Myrmicaris striata & * & * & $\bar{*}$ & \\
\hline Anelida & Eudrilus eugeniae & $*$ & $*$ & $*$ & - \\
\hline Macroarthropoda & Oniscus asellus & $*$ & $*$ & $*$ & * \\
\hline Anelida & Aporrectodae caliginosa & * & & & $*$ \\
\hline & Total & 23 & $\overline{21}$ & 20 & 18 \\
\hline
\end{tabular}

* represents the presence of mesofauna in the different forest type;

_ represents the presence of mesofauna in the different forest type 
Table 3. The abundance of litter arthropods in the studied habitats

\begin{tabular}{|c|c|c|c|c|c|c|}
\hline Family & Species & & & & & \\
\hline & & $\begin{array}{c}\text { Natural } \\
\text { forest }\end{array}$ & $\begin{array}{c}\text { Nauclea Diderichii } \\
\text { plantation }\end{array}$ & $\begin{array}{l}\text { Gmelina arborea } \\
\text { plantation }\end{array}$ & $\begin{array}{l}\text { Tectona grandis } \\
\text { plantation }\end{array}$ & Total \\
\hline Hemiptera & & 23 & 17 & 0 & 10 & 50 \\
\hline Hemiptera & & 3 & 0 & 0 & 0 & 3 \\
\hline Hemiptera & & 3 & 0 & 0 & 0 & 3 \\
\hline Hemiptera & Carponolus myamotricma & 0 & 3 & 0 & 0 & 3 \\
\hline Hemiptera & & 0 & 0 & 13 & 0 & 13 \\
\hline \multirow[t]{2}{*}{ Hemiptera } & Cassutia flaveole & 6 & 0 & 7 & 0 & 13 \\
\hline & Latrodectus mataus & 7 & 0 & 7 & 6 & 20 \\
\hline Diplopoda & & 3 & 3 & 0 & 0 & 6 \\
\hline Diplopoda & & 3 & 0 & 0 & 0 & 3 \\
\hline Diplopoda & & 0 & 10 & 0 & 0 & 10 \\
\hline Isoptera & Capius spp & 0 & 0 & 0 & 33 & 33 \\
\hline Culicidae & Cullex spp & 3 & 0 & 0 & 0 & 6 \\
\hline Coleptera & Sinoxylon senegalensis & 0 & 0 & 3 & 0 & 10 \\
\hline Coleptera & Chrysolagria colgi & 0 & 3 & 3 & 0 & 6 \\
\hline \multirow[t]{3}{*}{ Othoptera } & Zonocerus venegatus & 3 & 3 & 3 & 3 & 12 \\
\hline & Polyphmemus spp & 3 & 7 & 3 & 0 & 6 \\
\hline & Paracobla pennsylvanica & 10 & 3 & 0 & 0 & 10 \\
\hline Total & & 67 & 49 & 39 & 52 & 207 \\
\hline
\end{tabular}

Table 4. The species diversity of litter arthropods in the four studied habitats

\begin{tabular}{|c|c|c|c|c|c|c|}
\hline Family & Species & Local name & Natural forest & $\begin{array}{c}\text { Nauclea Diderichii } \\
\text { plantation }\end{array}$ & $\begin{array}{l}\text { Gmelina arbo- } \\
\text { rea plantation }\end{array}$ & $\begin{array}{l}\text { Tectona grandis } \\
\text { plantation }\end{array}$ \\
\hline Hemiptera & & Ant & $*$ & $*$ & _- & $*$ \\
\hline Hemiptera & & Ant & * & _ & _ & _ \\
\hline Hemiptera & & Ant & * & & - & - \\
\hline Hemiptera & Carponolus myamotricma & Ant & _- & * & - & - \\
\hline Hemiptera & & Ant & - & _ & $\bar{*}$ & - \\
\hline \multirow[t]{5}{*}{ Hemiptera } & Cassutia flaveole & & $\bar{*}$ & - & $*$ & - \\
\hline & & Spider & $*$ & - & & - \\
\hline & & Spider & * & - & $\bar{*}$ & - \\
\hline & Latrodectus mataus & Spider & _ & - & _ & $\bar{*}$ \\
\hline & & Spider & & & - & * \\
\hline Diplopoda & & Millipede & $\bar{*}$ & $\bar{*}$ & - & _- \\
\hline Diplopoda & & Millipede & $*$ & & - & - \\
\hline Diplopoda & & Millipede & - & $\bar{*}$ & - & - \\
\hline Isoptera & Capius spp & termite & - & - & - & $\bar{*}$ \\
\hline Culicidae & Cullex spp & mosquito & $\bar{*}$ & - & - & _- \\
\hline Coleptera & Sinoxylon senegalensis & & - & - & $\bar{*}$ & - \\
\hline Coleptera & Chrysolagria colgi & & - & - & $*$ & - \\
\hline \multirow[t]{9}{*}{ Othoptera } & Zonocerus venegatus & & $\bar{*}$ & $\bar{*}$ & & - \\
\hline & & Crane fly & & - & * & - \\
\hline & Polyphmemus spp & Moth & $\bar{*}$ & - & - & - \\
\hline & Paracobla pennsylvanica & & $*$ & - & - & - \\
\hline & & unknown & - & - & $\bar{*}$ & - \\
\hline & & unknown & - & - & _- & $\bar{*}$ \\
\hline & & unknown & - & $\bar{*}$ & - & _- \\
\hline & & Owl fly & - & $*$ & - & - \\
\hline & & unknown & - & $*$ & & \\
\hline Total & & & $\overline{67}$ & 49 & 39 & $\overline{52}$ \\
\hline
\end{tabular}

Table 5. The effect of the habitats and the period of collection on the abundance of mesofauna

\begin{tabular}{ccccccc}
\hline Source of Variation & SS & Df & MS & F & P-value & F crit \\
\hline Period of collection & 1176.188 & 3 & 392.0625 & 1.26401 & 0.3439 & 3.8628 \\
Habitat & 2903.188 & 3 & 967.7292 & 3.11996 & 0.0809 & 3.8625 \\
Error & 2791.563 & 9 & 310.1736 & & & \\
Total & 6870.938 & 15 & & & & \\
\hline
\end{tabular}

Table 6. ANOVA table showing the effect of the habitats and period of collection on Abundance the species diversity of mesofauna

\begin{tabular}{cccccccc}
\hline & Source of Variation & SS & Df & MS & F & P-value & F crit \\
\hline \multirow{2}{*}{ Abundance } & Period of collection & 1176.188 & 3 & 392.0625 & 1.26401 & 0.343852 & 3.862548 \\
& Habitat & 2903.188 & 3 & 967.7292 & 3.11996 & 0.08079 & 3.862548 \\
\hline \multirow{2}{*}{ Diversity } & Period of collection & 2.1875 & 3 & 0.729167 & 0.14094 & 0.932911 & 3.862548 \\
& Habitats & 18.6875 & 3 & 6.229167 & 1.204027 & 0.362744 & 3.862548 \\
\hline
\end{tabular}



and Plantation (A Case Study: Akure Forest Reserve Aponmu)

Table 7. The species diversity of bacteria in the study habitats

\begin{tabular}{|c|c|c|c|c|}
\hline Bacteria Species & Natural forest & $\begin{array}{c}\text { Nauclea Diderichii } \\
\text { plantation }\end{array}$ & $\begin{array}{c}\text { Gmelina arborea } \\
\text { plantation }\end{array}$ & $\begin{array}{c}\text { Tectona grandis } \\
\text { plantation }\end{array}$ \\
\hline Chrrobacterium spp & * & - & - & - \\
\hline Eschenchi coli & * & * & - & - \\
\hline Proten mirobilis & * & * & * & - \\
\hline Bacillus megaterium & * & - & - & - \\
\hline Alkaligenes spp & * & * & - & * \\
\hline Roteus megaterium & * & - & - & - \\
\hline Micrococus luteus & * & - & - & - \\
\hline Aeromonas spp & * & - & - & - \\
\hline Acinetobacta spp & * & * & - & - \\
\hline Pseudomonas aeniginosa & * & * & - & * \\
\hline Agrobacterium spp & * & - & - & - \\
\hline Methylococcus spp & * & $*$ & * & - \\
\hline Acetobacta spp & * & - & * & * \\
\hline Cellulomonas spp & * & - & - & - \\
\hline Bacillus cereus & * & * & * & - \\
\hline Klebsiolla spp & - & * & - & - \\
\hline Azotobacta paspali & - & * & - & * \\
\hline Acinmyces spp & - & * & - & * \\
\hline Kurthia spp & - & * & - & - \\
\hline Staphylococus aureus & - & * & * & * \\
\hline Azotobacta synugae & - & * & - & - \\
\hline Acrococcus aenogenes & - & - & * & * \\
\hline Citrobenta frelundi & - & - & * & * \\
\hline Panococcus spp & - & - & * & * \\
\hline Eruginia amyloiora & - & - & * & * \\
\hline Bacillus subtilis & - & - & * & * \\
\hline Streptococus feacal & - & - & * & - \\
\hline Azotobacta chrococeum & - & - & * & * \\
\hline Proteus vulgaris & - & - & * & - \\
\hline Corygnebacteriu spp & - & - & - & * \\
\hline Clostridium sporegenes & - & - & - & * \\
\hline Pseudomonus syrindea & - & - & - & * \\
\hline Clostridium plagarium & - & - & - & * \\
\hline Total & 15 & 13 & 13 & 16 \\
\hline
\end{tabular}

* represents the presence of bacteria in the different forest type

represents the presence of bacteria in the different forest type

Table 8. The species diversity of fungi in the four forest types

\begin{tabular}{|c|c|c|c|c|}
\hline Fungi Species & Natural forest & $\begin{array}{l}\text { Nauclea diderinchii } \\
\text { platation }\end{array}$ & $\begin{array}{c}\text { Gmelina arborea } \\
\text { plantation }\end{array}$ & $\begin{array}{l}\text { Tectona grandis } \\
\text { plantation }\end{array}$ \\
\hline Hunicola fuscoatra & * & - & - & * \\
\hline Botrytis anerea & * & - & * & - \\
\hline Pupalaris spp & * & - & - & - \\
\hline Penicillium italium & * & - & * & * \\
\hline Aspergillus niger & * & * & - & * \\
\hline Botryles cinerea & * & - & - & - \\
\hline Dectyllella brochopaga & * & - & - & - \\
\hline Penicellium notacum & $*$ & - & - & - \\
\hline Mucor muccolo & * & - & - & - \\
\hline Cereosporella porsica & $*$ & - & - & - \\
\hline Cercospora spp & * & - & - & - \\
\hline Cladosporium spp & * & - & - & - \\
\hline Passatra spp & * & - & - & - \\
\hline Sreptomyces spp & - & * & - & - \\
\hline Verticillium alboratrium & - & * & * & * \\
\hline Inchroderini viride & - & * & - & - \\
\hline Gonatobotrium apiculatum & - & * & * & - \\
\hline Srylopage spp & - & * & - & * \\
\hline Haplosporangium perium & - & * & - & - \\
\hline Aspergillus furigatus & - & * & * & * \\
\hline Ovilaris oviculoris & - & * & * & - \\
\hline Cladobotyum spp & - & * & - & - \\
\hline Dispora punctata & - & * & - & - \\
\hline Oidiodendron griseum & - & * & - & - \\
\hline Chrysosporium spp & - & * & - & - \\
\hline Aureobasidium spp & - & * & - & - \\
\hline Monilla sitophyla & - & * & - & - \\
\hline Asperomyces cruciatus & - & - & * & - \\
\hline Periconiella veluti & - & - & * & - \\
\hline Chloridium chlamydosporus & - & - & * & * \\
\hline Cryptostroma certicole & - & - & * & - \\
\hline Asteronyces crucoatus & - & - & * & - \\
\hline Mammaria echinobotryoides & - & - & * & - \\
\hline Umbelospsis spp & - & - & * & - \\
\hline Pleurothecium $s p p$ & - & - & * & - \\
\hline Menispora cobaltina & - & - & * & - \\
\hline Vergeria spp & - & - & * & - \\
\hline Streptotrix atra & - & - & $*$ & * \\
\hline Penicillium vlutina & - & - & * & * \\
\hline Articulospora inflate & - & - & * & \\
\hline
\end{tabular}


Table 8. The species diversity of fungi in the four forest types (Continued)

\begin{tabular}{ccccc}
\hline Busidiobotrys spp & - & - & - & $*$ \\
Sreptothrix spp & - & - & - & $*$ \\
Gyrothrix ancinta & - & - & - & $*$ \\
Aspergillus flavus & - & 15 & 19 & $*$ \\
Total & 13 & & 13 \\
\hline
\end{tabular}

* represents the presence of fungi in the different forest type

_represents the absence of fungi in the different forest type

Table 9. ANOVA table for the effect of the habitat types on the abundance of bacteria and fungi in the study habitat

\begin{tabular}{cccccccc}
\hline & Source of Variation & SS & Df & MS & F & P-value & F crit \\
\hline Abundance of Bacteria & Habitats & 0.010 & 3 & 0.0033 & 0.0811 & $0.9695 \mathrm{~ns}$ & 3.0983 \\
\hline Abundance of Fungi & Habitats & 0.4450 & 3 & 0.1483 & 0.5027 & 0.6852 & 3.1599 \\
\hline
\end{tabular}

Table 10. Relationship between the abundance and species diversity of mesofauna and litter arthropods, bacteria and mesofauna, bacteria and litter arthropods, fungi and mesofauna and fungi and litter arthropods in the different habitats of the study area

\begin{tabular}{|c|c|c|c|c|c|}
\hline & EQUATION & $\mathrm{R}$ & $\mathrm{R}^{2}$ & P-Value & Remark \\
\hline Relationship between abundance of mesofauna and litter arthropods & $Y=-0.0321 X+18.3826$ & 0.1326 & 0.0176 & 0.8674 & Ns \\
\hline Relationship between species diversity of mesofauna and litter arthropods & $Y=1.4571 X-22.4857$ & 0.9954 & 0.9908 & 0.0046 & $*$ \\
\hline Relationship between abundance of bacteria and mesofauna & $Y=0.0019 X+70.1488$ & 0.0246 & 0.0006 & 0.975371 & Ns \\
\hline Relationship between species diversity of bacteria and mesofauna & $Y=-0.1111 X+22.3333$ & 0.0976 & 0.0095 & 0.9024 & Ns \\
\hline Relationship between abundance of fungi and mesofauna & $Y=0.0668 X+71.5937$ & 0.0513 & 0.0026 & 0.9487 & Ns \\
\hline Relationship between species diversity of fungi and mesofauna & $Y=-0.1667 X+23.2500$ & 0.2760 & 0.0781 & 0.7239 & Ns \\
\hline Relationship between abundance of bacteria and litter arthropods & $\mathrm{Y}=0.0133 \mathrm{X}-11.9856$ & 0.6943 & 0.4820 & 0.3057 & Ns \\
\hline Relationship between species diversity of bacteria and litter arthropods & $Y=-0.2592+11.4444$ & 0.1556 & 0.0246 & 0.8444 & Ns \\
\hline Relationship between abundance of fungi and litter arthropods & $Y=-0.2100+24.7445$ & 0.6979 & 0.4871 & 0.32819 & Ns \\
\hline Relationship between species diversity of fungi and litter arthropods & $\mathrm{Y}=-0.1667+10.25$ & 0.1885 & 0.0356 & 0.8114 & Ns \\
\hline
\end{tabular}

$*=$ significant. Ns $=$ not significant

Table 11. Correlation between abundance of litter arthropods, mesofauna, bacteria, and fungi in the studied habitats

\begin{tabular}{|c|c|c|c|c|}
\hline & litter arthropod's abundance & mesofauna abundance & bacteria count & fungi count \\
\hline litter arthropod's abundance & 1 & & & \\
\hline mesofauna abundance & -0.1326 & 1 & & \\
\hline bacteria count & 0.6943 & 0.0246 & 1 & \\
\hline fungi count & -0.6979 & 0.0513 & -0.9970 & 1 \\
\hline
\end{tabular}

Table 12. Correlation between species diversity of litter arthropods, mesofauna, bacteria, and fungi in the studied habitats

\begin{tabular}{|c|c|c|c|c|}
\hline & $\begin{array}{l}\text { litter arthropod's } \\
\text { species diversity }\end{array}$ & $\begin{array}{c}\text { mesofauna specie } \\
\text { diversity }\end{array}$ & $\begin{array}{c}\text { bacteria spp } \\
\text { diversity }\end{array}$ & $\begin{array}{l}\text { fungi spp } \\
\text { diversity }\end{array}$ \\
\hline litter arthropod's species diversity & 1 & & & \\
\hline mesofauna specie diversity & 0.9954 & 1 & & \\
\hline bacteria spp diversity & -0.1556 & -0.0976 & 1 & \\
\hline fungi spp diversity & -0.1886 & -0.2760 & -0.7857 & 1 \\
\hline
\end{tabular}

\section{Discussion}

\section{Effect of Plantation Development on Mesofauna}

The results in Table 1 and 2 showed that Gmelina arborea plantation has the highest abundance of mesofauna (334 individuals) followed by Tectona grandis plantation (316) while the natural forest ranked third with 314 individuals and Nauclea diderichii plantation recorded the least with abundance of 201. The highest species diversity of mesofauna was found in the natural forest (23), while the least was recorded in Tectona grandis plantation (18). This result implies that more species of mesofauna tends to lives in an undisturbed area, and since the natural forest used in this study is not disturbed in any form compared with various plantations used in this study. This result is similar to the observation of Rapport's (1983) who reported that mesofauna lives where there is minimum disturbance of forest ecosystem.

Table 5, shows that plantation development does not sig- nificantly affect the abundance of mesofauna. This result is in line with the report of Evans (1999) who reported that the abundance of mesofauna in the plantation is not lower than that of Natural forest.

Plantation development does not significantly affect the diversity of mesofauna (Table 6). However the natural forest have higher species diversity value than the plantations on the average though the differences are very small this is still in line with Rapport (1983) who reported that natural forest (undisturbed forest) has more species diversity than plantations.

Table 6, shows that there was no significant effect in the difference in the habitats that the survey was carried out on the species diversity of mesofauna, the insignificance in the effect of the difference in habitats on the diversity of mesofauna suggesting that plantation development do not have significant effect on the species diversity of mesofauna.

Effect of Plantation Development on Litter Arthropods

From the result in table 3 and 4, 64 individuals litter ar- 
thropods were encountered in the study area with 27 species. Highest values were recorded for both abundance and species diversity in natural forest. Tectona grandis plantation was next in number of individual but least in species diversity (16 individuals and 5 species); Nauclea diderichii plantation has 15 individuals and 8 species while Gmelina arborea plantation has the least number of individuals (12) and 7 species. From the result of this study, plantation development seems to affect both the abundance and species diversity of litter arthropods negatively (it reduces both the species diversity and the abundance of litter arthropods). This may be due to the fact that arthropods like mesofauna preferred an undisturbed forest ecosystem which the natural forest provides. However contrary to some researches reports that fauna abundance (arthropods inclusive) is not necessarily more in the natural forest than the plantation (e.g. Evans, 1999) the development of plantation has negatively affected the abundance of litter arthropods this may be due to the heterogeneity of the natural forest and the fact that the litter quality is better than that of the plantation.

\section{Effect of Plantation Development on Microorganisms}

Table 7 and 8 , shows that the total of about 33 different species of bacteria were found in the study habitats, Tectona grandis plantations having the highest species diversity of bacteria (16 species are discovered in the plantation) followed by the natural forest with 15 species while both $\mathrm{Nau}$ clea and Gmelina plantation having equal species diversity of 13 species of bacteria each. About 44 species of fungi was also found across the forest types with the highest being Gmelina arborea plantation (19 species was discovered in the plantation) followed by Nauclea diderichii plantation (15 species) while natural forest and Tectona grandis plantation shares the least diversity of fungi (13 species each). However From the table 9 and 10, the different habitats does not have a significant effect on the abundance of bacteria and fungi species present in the different forest type this may be due to the fact that the four forest types are subjected to the same climatic and edaphic conditions since they are all in the same ecological zone (i.e. Akure Forest Reserve Aponmu which is a Tropical Rain Forest.)

Relationship Between Litter Arthropods and Mesofauna

Table 10 to 12 , show the regression equation between change in the abundance of mesofauna and litter arthropods $(\mathrm{Y}=-0.0321 \mathrm{X}+18.3826)$ is not significant $(\mathrm{P}>0.05)$, the relationship between mesofauna and litter arthropods very low $(R=0.1326)$ while the regression equation between change in the species diversity of mesofauna and litter arthropods $(\mathrm{Y}=0.0019 \mathrm{X}+70.1488)$ is significant $(0.0046)$ and relationship between them is very strong $(\mathrm{R}=0.9954)$. Also the correlation between the abundance and species diversity of mesofauna and litter arthropods (- 0.1326 and 0.9954 ) is negatively very low and positively very high respectively, this implies a change in mesofauna abundance will cause a very weak negative change in the abundance of litter arthropods as we moves from one habitat to the other habitat. While an increase in the species diversity of mesofauna between the habitats will cause a positive change in species diversity of litter arthropods. The negative relationship between abundance of mesofauna and litter arthropods may be due to the fact that some mesofauna are predator to even macro arthropods like the litter arthropods (e.g., entomopathogenic nematodes feed on insects and other larger invertebrates) FAO (2004). It may also be due to the fact that some soil arthropods (e.g. the Harvester ants "Pogonomyrmex spp." create and maintain vegetation-free zones around their nests by removing debris and clipping the vegetation.) creates their own microclimates themselves which may not be favourable for the presence of other soil fauna this may cause the absence of other arthropods including mesofauna which preferred an undisturbed forest habitat (MacMahon et al., 2000, Rapport 1983) the strong positive relationship between mesofauna species diversity and litter arthropod's species diversity is expected since the same edaphic and environmental conditions favours them (Wikipedia, 2008).

\section{Relationship between Arthropods and Microorganisms (Bacteria and Fungi)}

The regression equation between abundance and species diversity of mesofauna and bacteria, mesofauna and fungi, litter arthropods and bacteria and litter arthropods and fungi were not significant. The rate at which the changes in bacteria and fungi abundance and species diversity affects changes in mesofauna abundance and species diversity (i.e. $\mathrm{R}=0.2760,0.0976,0.0513$ and 0.0246 respectively) is very weak. While the rate at which the abundance of bacteria and fungi affects the abundance of litter arthropods (i.e. $\mathrm{R}=$ 0.6943 and 0.6979 ) is fairly strong, however the rate at which change in species diversity of bacteria and fungi affects litter arthropods (i.e. $\mathrm{R}=0.1556$ and 0.1885 ) is very weak.

The correlation between bacteria and fungi abundance and species diversity that of mesofauna (i.e. 0.024629, 0.051321, -0.27603 and -0.09759 ) is weak. While the correlation between their abundance is positively weak, the correlation between their species diversity is negatively weak. This means that a change in the abundance of bacteria and litter arthropods in a habitat will cause a relatively small change in the abundance of mesofauna between the habitat this may be so small that it will not be noticeable while a change in species diversity of fungi and bacteria will cause a negative small change in the species diversity of mesofauna. This result is however contrary to some researches (e.g. Folgarait, 1998, Brown et al 2000) in the past which proves that there is a symbiotic relationship between soil microorganisms and mesofauna, however the result of this survey may have been caused by the fact that the conditions that affects the suitability of the different habitats for both mesofauna and microorganisms varies.

From the same table 10 and 11 , the correlation between abundance of bacteria and fungi and litter arthropods ( 0.6943 and -0.6979 respectively) is fairly high while the correlation between bacteria and litter arthropods is positive that between fungi and litter arthropods is negative. However the correlation between the species diversity of both bacteria and fungi and litter arthropods ( -0.1556 and -0.1886 respectively) 
is negatively low. This means that the change in bacteria abundance and species diversity between the forest habitats will cause a fairly high change in the abundance and negatively low change in the species diversity of litter arthropods in the different habitats. While the change in abundance and species diversity of fungi in the habitats will cause a negative fairly high change in the abundance and low change in the species diversity of litter arthropods in the different habitats. The result on the abundance may be due to the symbiotic relationship between bacteria and litter arthropod (especially those that are ecosystem engineers e.g., ant, termites, etc) Brown et al (2000). While the negative correlation between fungi and litter arthropods may have been caused by the effect of some fungi (e.g. Aspergillus spp) that are antibiotic organisms therefore they reduces presence of other microorganisms that could have break down the forest litters that serves as food for litter arthropods thereby affecting their abundance negatively.

\section{Conclusions}

The plantation development has little effect on the abundance and species diversity of mesofauna. Plantation development does not significantly affect the abundance and species diversity of litter arthropod. The changes in abundance of mesofauna in forest habitats does not significantly affect the change in abundance of litter arthropods in the different forest habitat however the change in species diversity of mesofauna in a forest habitat have a positive strong influence on the species diversity of litter arthropods that will be present in the different habitats.

The change in abundance and species diversity of both fungi and bacteria species in the study habitats does not have a significant affects on the abundance and species diversity of mesofauna. The changes in abundance of both bacteria and fungi in between habitats will cause a fairly strong change in the abundance of litter arthropod in the different habitat, while change in species diversity of both bacteria and fungi do not have noticeable effect on the change in species diversity of litter arthropod.

\section{REFERENCES}

[1] Adeduntan, S. A. Ofuya, T.I. and Fuwape, J. A. (2005).Environmental Effect of Insect Herbivores and logging on Tree Species Diversity in Akure Forest Reserve (Aponmu). Applied Tropical Agriculture. Vol. 09: 12-18.
[2] Adeduntan, S. A. (2009). Influence of Human Activities on Diversity and Abundance of Insects in Akure Forest Reserve, Ondo State Nigeria. International Journal of Biological and Chemical Sciences. 3(9):1320-1335.

[3] Adeduntan, S.A.., Ofuya, T.I. and Fuwape, J.A. (2006): Influence of Land Use System on Diversity and Abundance of Insects in Akure Forest Reserve, Ondo State Nigeria. Conference on International Agricultural Research for Development. University of Kassel-Witzenhausen and University of Gö ttingen.

[4] Alexander, M.E. (1982). Calculating and interpreting forest fire intensities. Canadian Journal of Botany. 60 (4): 349-357.

[5] Anna Thanukos (2007): The Arthropod Story University of Califonia, Berkeley.( http // evolution. Berkeley. Edu/evolibrary/ article/ arthropodstory).

[6] Brown, G.G., Barois, L., Levelle, P., (2000). Regula tion of soil organic matter dynamics and microbial activity in the drilosphere and the role of interactions with other edaphic functional domains. Eur. J., Soil Biol. 36, 177-198.

[7] Evans, J. (1999): Sustainability of Forest Plantations: the evidence. Review of evidence concerning the narrow sense sustainability of planted forests. Department of International Development (DFID), Issues Paper, May 1999.DFID, U.U. 64 pp. ISBNI 861920997.

[8] FAO, (2004): Conservation and Management of Soil Biodiversity and soil it's in Sustainable Agriculture. Information Resource and Water Themes.. On-line publications.

[9] Folgarait, P.J., (1998). Ant biodiversity and its relationship to ecosystem functioning: a review. Biodivers. Conserv. 7,1221-1244.

[10] MacMahon, J.A., Mull, J.F. and Crist, T.O., (2000). Harvester ants (Pogonomyrmex spp. ): their community and ecosystem influences. Annu. Rev. Ecol. Sysst. 31.265-291.

[11] Marshall S.A., Anderson R.S., Roughley R.E., Behan-Pellletier V., and Danks, H. V. (1994): Biologiica Surveyof Terrestrial Arthropods. A Brief Prepared by the Biological Survey of Canada (Terrestrial Arthropods). Originally published by the Entomological Society of Canada Supplement to the Bulletin, Vol.26 (1), March 1994

[12] Ola-Adams, B.A. and Hall, J.B(1987): Soil plant relation in a National Inviolate plot at Akure, Nigeria. Journal of Tropical Ecological. Vol. 3.pg 57-79.

[13] Rapport, R.I. (1983). Indicators of water quality from an ecosystem perspective. 12pp. manuscript for "Informal Meeting on Water Use and Quality Statistics" at Conference of European Statisticians, Geneva, 12-14 Dec. Statistics Canada, Ottawa Ont.

[14] Wikipedia, H. (2008): Arthropods, Wikipedia the free encyclopedia. Wikimedia Foundation, Inc., U.S http//en.wikipedia.org/wiki/Arthropod. 